\title{
LIQUIDITY RISK AND ITS MANAGEMENT IN LITHUANIAN BANKING SYSTEM
}

\author{
Erika Bareikaite் ${ }^{1}$, Raimonda Martinkutè-Kaulienè ${ }^{2}$ \\ Vilnius Gediminas Technical University \\ E-mails: ${ }^{1}$ erika.bareikaite@gmail.lt; ${ }^{2}$ raimonda.martinkute@vgtu.lt
}

\begin{abstract}
Banks are the main part of financial sector in each economy and strength of banking system becomes vital for ensuring favourable economic stability and growth. Recent failure of two commercial banks in Lithuania showed that managers haven't evaluated liquidity risk or haven't dealt with it properly. The tasks of the paper are to investigate Lithuanian banks position towards liquidity risk, analyse what kind of management tools banks use for ensuring favourable position towards liquidity and to explore the liquidity influence to profitability in Lithuanian banking sector. The article examines liquidity and its management processes in Lithuanian banking sector. Description of liquidity importance is presented. Liquidity risk and its measurement as well as the ways of managing the above mentioned risk is analysed in the article. In order to analyse the relationship between liquidity risk and profitability of banks, analysis of scientific literature, research synthesis and generalizations have been made.
\end{abstract}

Keywords: liquidity, liquidity risk, bank’s liquidity management, liquidity ratios, Lithuanian banking system.

\section{Introduction}

In today's context of globalization, the strength of banking system becomes vital for ensuring favorable economic stability and growth. Banks are the main part of financial sector in each economy by enhancing flow of funds and providing liquidity (Diamond, Rajan 2001). Moreover, banks stimulate the smoothness in goods and services markets and provide possibility to market members to make productive investments. In this manner banks stimulate innovation and help to develop new industries, what leads to improved employment rate and overall stability of the economic (Arif, Nauman 2012).

In order to capture the benefits that well organized banking system can bring, banks have to be able to control its stability and manage risks. Liquidity risk is a risk that bank will not be able to cover obligations for its depositors. It is one of major todays issues that bank have to deal with (Jenkinson 2008).

Recent failure of two commercial banks in Lithuania showed that managers haven't evaluated liquidity risk or haven't dealt with it properly. The issue of liquidity became vital for banks from marketing site, when a lot of members of society in Lithuania have lost trust in banking system.

However, maintaining a defensive liquidity risk position and management is extremely challenging and difficult in today's competitive and open economic system with strong external influences and sensitive market players (Siddiqi 2008). Successful and well-organized banks must have stable system not only for evaluation but also for management of liquidity risk.

The aim of the article is to investigate liquidity influence to Lithuanian banks performance. In order to achieve the aim such tasks should be implemented: to describe the liquidity risk, as well as to identify importance of stable position towards liquidity, moreover, to identify what means for liquidity risk measurement can be used, analyze what kind of management tools can be applied in banks for ensuring favorable position towards liquidity and lastly - to describe in what possible manner liquidity influence to profitability in Lithuanian banking sector could be explored.

In order to fulfill tasks and achieve the aim of the paper analysis of scientific literature and normative documents, comparison and synthesis was made.

\section{Importance of liquidity in business}

To begin with, identifying importance of liquidity it is a must to understand meaning of the term "liquidity". CEO of Gerrard and King Mr. Jones expressed liquidity as "the ability, at minimum cost, time and spread, to convert an asset to cash." In online business dictionary liquidity is expressed as "a measure of the extent to which a person or organization has cash to meet immediate and short- 
term obligations, or assets that can be quickly converted to do this". While Bob Falconer, head of Asset Liability Management with ABN AMRO Bank NV in London named that liquidity represents a bank's ability to accommodate decreases in its liabilities and its ability to fund increases in its assets (Falconer 2001).

The liquidity in simplified terms is companies' ability to cover its obligations towards creditors calling funds at inconvenient time, expressed in measured number. In other words, if the liquidity is not managed in proper way, firm can face situation of illiquidity and will technically be bankrupt or face losses. No manager wants to lead a company to this situation. That is main reason why companies have to be aware of liquidity risk management. Managers have to be ready to adapt to unfavorable economic conditions and possible changes in order to stay in the market and not to damage company's image and relationships with stakeholders (Hawawini, Vialler 2007).

The recent global financial crisis that started in 2007 occurred because of the failures in derivatives markets which negatively caused banks' ability to provide liquidity to third parties. That shows that problems commonly came up after failures in the management of funds or unpredicted unfavorable economic conditions which lead to unpredictable liquidity withdrawals by the depositors (Siddiqi 2008).

Another example of liquidity urgency is failure and demise of Long-Term Capital Management in 1998 that caused dollar/yen rate to move from 131 to 118 . According to CEO of Gerrard and King Mr. Jones it was caused by liquidity problem (Ross 2000).

To sum up, the liquidity means companies' ability to cover its obligations without experiencing losses. Out of that there is clear view of liquidity importance: if a company or institution is not liquid enough it will suffer financially. There can be a lot of examples through history found confirming the importance of appropriate management of liquidity. Banks should be equipped to deal with the changing monetary policy that shapes the overall liquidity trends and the banks' own transactional requirements and repayment of short term borrowing (Akhtar 2007).

\section{Liquidity risk and its management in banking sector}

In literature sources (Jenkinson 2008; Diamond, Rajan 2001; Chaplin, Emblow et al. 2000) there are a lot of different definitions explaining liquidity risk found. According a comptroller of the currency acting in USA "Liquidity risk is a risk arising from a bank's inability to meet its obligations when they come due without incurring unacceptable losses" (Comptroller of the Currency 2001). While other literature analysis showed that liquidity risk - the risk that a bank may not meet its obligations (Jenkinson 2008) as the depositors may call their funds at an inconvenient time, causing fire sale of assets (Diamond, Rajan 2001), negatively affecting profitability of the bank (Chaplin, Emblow et al. 2000). According to The Bank of Lithuania it is the risk to meet difficulties in realizing financial asset fast and without losses (LB 2012). According to State Bank of Pakistan: Liquidity risk is the potential for loss to an institution, arising from either its inability to meet its obligations or to fund increases in assets as they fall due without incurring unacceptable cost or losses. So, in easier terms, liquidity risk can be defined as the risk of being unable to liquidate a position timely at a reasonable price (Muranaga, Ohsawa 2002).

The risk can influence both bank's capital and its earnings. If the risk is over valuated - bank cannot invest its funds in more profitable illiquid assets, so earnings will suffer. If bank is under evaluating the risk it might have to handle fire sales and not surely to reasonable price, so it can damage the capital. This is why it becomes the top priority of a bank's management to ensure the availability of sufficient funds to meet future demands of providers and borrowers, at reasonable costs.

Moreover, bank's position towards liquidity risk affects not just its performance but bank's reputation also (Jenkinson 2008). If the bank will be late by providing funds for depositors, it will look not trustful and unsafe. The bank may lose confidence and at the same time clients. The bank's reputation may become at stake in that kind of situation (Arif, Nauman 2012).

Liquidity risk has become a serious concern for the banks because of high competition for consumer deposits and new wide assortment of funding products in wholesale and capital markets with technological advancements. The funding and risk management structure has completely been changed (Akhtar 2007). A bank having good asset quality, strong earnings and sufficient capital may fail if it is not maintaining adequate liquidity (Crowe 2009), that is why management of liquidity risk became one of major bank's success factors.

Furthermore, liquidity risk management is an essential component of the overall risk management framework, especially of the financial services industry, concerning all financial institutions (Majid 2003). As financial institution, banks should manage the demand and supply of liquidity in an appropriate manner in order to safely run their business, maintain good relations with the stakeholders and avoid liquidity problem (Ismal 2010). Well-managed bank 
should have a well-defined mechanism for the identification, measurement, monitoring and mitigation of liquidity risk (Comptroller of the Currency 2001). A well-established system helps the banks in timely recognition of the sources of liquidity risk to avoid losses in both cases - undervalued liquidity risk and overvalued liquidity risk.

The balance sheets of banks are growing in complexity and dependence upon the capital markets what has made the liquidity risk management more challenging (Guglielmo 2008). The banks regularly find the liquidity imbalances between asset and liability side that needs to be equalized because banks issue liquid liabilities but invest in illiquid assets and result as liquidity risk which can end with losses for the bank (Zhu 2001). In other words, if a bank fails to balance the gap, liquidity problems might occur followed by some unwillingness exposures such as high interest rate risk, high bank reserves or capital requirement, and lower bank's reputation. Therefore, the ability of the bank to manage liquidity risk is very imperative to maintain the continuity of banking operations and stay competitive (Ismal 2010).

\section{Regulation of liquidity risk for banks}

In banking sector both investors and borrowers are concerned about liquidity. Investors desire liquidity because they are uncertain about when they will want to eliminate their holding of a financial asset. Borrowers are concerned about liquidity because they are uncertain about their ability to continue to attract or retain funding (Diamond, Rajan 1999). Liquidity risk of course is important in any type of business, but because of banks' performance in providing liquidity for others and previously mentioned high impact to whole economy, the banks' liquidity is governed by the governmental instruments. In the aftermath of the 2007-2009 financial crisis bank regulators devised Basel III, a new rulebook that includes several measures to strengthen the resilience of the banking sector (Varotto 2011).

Basel III is an international framework for liquidity risk measurement, standards and monitoring issued at 2009 and edited at December 2010. According to it one of the key lessons of the crisis has been the need to strengthen the risk coverage of the capital framework. Failure to capture major on- and off-balance sheet risks, as well as derivative related exposures, was a key destabilizing factor during the crisis.

In response to these shortcomings, the reforms raise capital requirements for the trading book and complex securitisation exposures, a major source of losses for many internationally active banks. The enhanced treatment introduces a stressed value-at-risk capital requirement based on a continuous 12-month period of significant financial stress. In addition, the Committee has introduced higher capital requirements for so-called re-securitisation in both the banking and the trading book.

Banks always were required to have a minimum amount of capital to be able to absorb losses and still operate during the crisis. Moreover, the central bank imposes the condition of cash reserve requirement to survive unexpected liquidity problems. As a rule, bank always tries to avoid the capital injection from the government because this may place a given bank at the government's mercy (Jeanne, Svensson 2007). Therefore, banks hold minimum cash balance to avoid liquidity problems (Jenkinson 2008; Arif, Nauman 2012). However, during the recent crisis, the losses that banks suffered in their trading books have far exceeded minimum capital requirements (BCBS 2009c). As a result, the Basel Committee has undertaken an extensive revision of bank regulation, which has resulted in several new measures (BCBS 2009c, 2010b). To increase the loss-absorbing capacity of bank capital the Basel Committee has introduced two additional capital requirements for the trading book, the "incremental risk capital" charge and the stressed value-at-risk.

\section{Liquidity as management indicator}

In extreme situations a vague management of liquidity may cause liquidity crisis which often results in a bank using up its reserve of liquid assets and being unable to replace its maturing liabilities. As a consequence, the bank would have to sell its less liquid assets at unfavorable conditions and probably prices lower than market's price (Falconer 2001). Therefore, the management of liquidity is a serious business which can show banks management position.

Generally speaking, it might be that if bank is more liquidity aware it is probably safe, trustful but will have higher services prices. Whereas, if the bank's position towards liquidity is just exceeding minimum required liquidity ratio bank is probably more profitable and is able to lower its services' prices, however it is not so safe and trustful as in a first case. Balance sheet liquidity management is concerned with the trade-off between the lower returns on liquid assets relative to the higher returns on illiquid assets. Or to put it in terms of the other side of the balance sheet, the trade-off between the lower cost of volatile funding is relative to the higher cost of stable funding. Dedicated liquidity management information systems have an essential part to play in getting these balances right (Falconer 2001).

This leads to an outcome, that bank's position towards liquidity can show its priorities and indicate management 
style. At first there is a need to look and examine bank's organizational structure of liquidity management and then to state how liquidity and its risk is measured and controlled inside a bank.

\section{Components for assessing liquidity}

According to Bob Falconer (2001), head of Asset Liability Management with ABN AMRO Bank NV in London, there is a need to examine a bank's balance sheet as it appears in its annual report and reformats the contents from a liquidity perspective in order to see bank's liquidity position (Falconer 2001).

In addition, a sound basis for evaluating asset liability (asset liability management is the process of managing the spread between interest earned and interest paid while ensuring adequate liquidity) management requires an understanding of the bank, its customer mix, the nature of its assets and liabilities, and its economic and competitive environment. Because no bank has the same state of mentioned aspects, no single theory can be applied universally to all banks. However, there most universal way to measure structural liquidity can be found. It is the underlying relationship between long-term illiquid customer loans and stable funding. Because the funding is paramount therefore a bank should be continuously aware of the breakdown of its sources of funding in terms of different categories of customers, financial markets and instrument and keep its robust liquidity position through balance.

Similar perception can be expressed through matching strategy. In other words it states, that firms' long term assets should be covered by long-term financing source and short-term investments by short-term debt. By matching the life of an asset and the duration of its financing source, a firm can minimize the risk of not being able to finance the asset over its entire useful life. However, for most firms, the matching strategy is an objective rather than a day-today reality. The goal of management is for long-term funds to match the firm's long-term investments or putting in accounting terms net fixed assets and most of the working capital requirement and for short-term funds to match the firm's short-term investments (cash and marketable securities) over time (Hawawini, Vialler 2007).

As components for balancing the liquidity is already known, there is a need to examine how banks are measuring the liquidity and state if it is balanced. According to Hawawini, G. and Vialler, C. (2007), there is a need to turn the standard balance sheet into managerial one. What means that operating assets should be less than operating liabilities in constraining working capital requirement (WRC) line in the managerial balance sheet. After calculating WRC, which also have to be covered by long term financing using matching strategy because of constant repeating of operating cycle, it is needed to calculate Net long term financing (NLF) to be able calculate liquidity ratio. The NLF is the difference between long term financing and net fixed assets. By knowing the WRC and NLF formulas we can express the ratio of liquidity which is NLF divided by WCR. In this case the higher the ratio is, the more liquid an institution is.

It is important to banks to measure liquidity risk, because the accurate measurements can help to avoid the risk by focusing on the ratios like liquid assets to total assets and liquid liabilities to total liabilities (Goddard, Molyneux et al. 2009). In literature analysis there can be more ways for calculating the current liquidity of a firm. For example, the two most often mentioned liquidity ratios are the current ratio and the quick ratio. The current ratio is defined as the ratio between the firm's total current assets and its current liabilities. The quick ratio disaggregates the total current assets into an inventory component and a non-inventory component, and divides the latter by the firm's current Habilities (Peles, Schneller 1979).

In addition, liquidity ratios helps to identify the current situation of liquid to illiquid assets in a bank, however, banking risks control requires a standard measurement that can compare the potential loss produced by the individual financial positions. The methodology most often used is the value-at-risk (further - VaR). The VaR can be defined as the largest likely loss from market risks that an asset or portfolio will suffer over a time interval and with a degree of certainty selected by the decision-maker. It is expressed in currency units (Titus, Lewis 1997). In other words, VaR provides possibility to figure the minimum capital required to bear the maximum loss, computed according to five factors:

1) volatility of prices, interest and exchange rates;

2) probability distribution of likely returns;

3) time horizon;

4) confidence interval;

5) correlation among different positions.

However, the worst-case scenario does not consider the impact of liquidity on capital loss. For this reason LaVaR - liquidity adjusted value at risk is often used. The LaVaR is simply modification of VaR. Liquidity-adjusted VAR incorporates exogenous liquidity risk into Value at Risk. It can be defined as VaR plus exogenous liquidity cost (ELC). The ELC is the worst expected half-spread at a particular confidence level (Bervas 2006).

Summing up, there is a number of ways how companies measure the liquidity risk. Managers can reorganize the 
balance sheet in order to see the clearer view. There can be the matching strategy used in order to see if funding and investment period is compatible and if there is risk for illiquidity or isn't. Moreover, quick and adjusted quick ratios can be used in order to express the ratio between liquid and illiquid assets. Striving to evaluate the worst case scenario VaR or LaVaR may be applied.

\section{Liquidity management in Lithuanian banking system}

In Lithuania as in many other countries central bank, called The Bank of Lithuania, acts. Its main objective is price stability performed by Lithuanian economic monitoring, analysis, and the economic development prospects. The Bank of Lithuania is issuing licenses for financial institutions and govern them and observes the changes and performance of the banking sector (The Bank of Lithuania 2013). The Bank provides statistics about banking sector which is as follow.

According to the Bank of Lithuania, in the country in first quarter of 2013 there acted 16 banks out of which 7 were Lithuanian capital banks, and 9 branches of foreign banks. Moreover, there were registered 75 credit unions with 1 central credit union and 10 leasing companies. Also, there were eleven insurance companies, 123 capital market members and 39 pension funds. In total, in Lithuanian financial sector acted 275 members (see Table 1).

The organizational structure of liquidity management varies through different banks. Still, according to Bob Falconer (2001) in some banks liquidity management will be the responsibility of group treasury while in other banks there will be a split in responsibilities between the treasury department and the asset liability management function. Where there is a split, the treasury department normally looks after the short-term day-to-day cash flow management while the asset liability management function will have responsibility for the longer-term structural liquidity of the bank's balance sheet and the maintenance of a contingency funding plan.

One commercial bank in Lithuania declares that liquidity management and control function are incorporated in risk management and control department and is based on the concept of three levels of protection:

- the first level of protection - risk management is carried out by direct customer service department managers and employees;

- the second level of protection is provided by an independent credit compliance and operational risk offices (risk control units);
Table 1. Structure of Lithuanian Financial Sector Source: The Bank of Lithuania.

\begin{tabular}{|c|c|c|c|c|c|}
\hline & $\begin{array}{c}\text { Num- } \\
\text { ber }\end{array}$ & $\begin{array}{l}\text { Assets, } \\
\text { LTL } \\
\text { million }\end{array}$ & $\begin{array}{l}\text { Assets, } \\
\%\end{array}$ & \begin{tabular}{|c|} 
Change in \\
assets in \\
Q1 2013, \\
$\%$
\end{tabular} & $\begin{array}{l}\text { Assets } \\
\text { as } \% \\
\text { of } \\
\text { GDP }\end{array}$ \\
\hline Banks & 16 & $77304 *$ & 81.1* & $4.1 *$ & $67.5^{*}$ \\
\hline $\begin{array}{l}\text { Banks, } \\
\text { excluding } \\
\text { foreign bank } \\
\text { branches }\end{array}$ & 7 & $62043^{*}$ & $65.1 *$ & $6.5^{*}$ & $54.2 *$ \\
\hline $\begin{array}{l}\text { Foreign bank } \\
\text { branches }\end{array}$ & 9 & 15260 & 16.0 & -4.5 & 13.3 \\
\hline Credit unions & 75 & 2030 & 2.1 & -1.3 & 1.8 \\
\hline $\begin{array}{l}\text { Central credit } \\
\text { union }\end{array}$ & 1 & 402 & 0.4 & 8.6 & 0.4 \\
\hline $\begin{array}{l}\text { Leasing } \\
\text { companies }\end{array}$ & 10 & 5744 & 6.0 & -1.2 & 5.0 \\
\hline $\begin{array}{l}\text { Insurance } \\
\text { companies }\end{array}$ & 11 & 2792 & 2.9 & -6.5 & 2.4 \\
\hline $\begin{array}{l}\text { Life assurance } \\
\text { companies }\end{array}$ & 5 & 1801 & 1.9 & 1.3 & 1.6 \\
\hline $\begin{array}{l}\text { Non-life } \\
\text { insurance } \\
\text { companies }\end{array}$ & 6 & 991 & 1.0 & -17.9 & 0.9 \\
\hline $\begin{array}{l}\text { Capital market } \\
\text { participants }\end{array}$ & 123 & 1953 & 2.1 & 6.0 & 1.7 \\
\hline $\begin{array}{l}\text { Financial } \\
\text { brokerage } \\
\text { firms }\end{array}$ & 9 & 20 & 0.0 & -21.4 & 0.0 \\
\hline $\begin{array}{l}\text { Management } \\
\text { companies }\end{array}$ & 14 & 80 & 0.1 & 2.7 & 0.1 \\
\hline $\begin{array}{l}\text { Collective } \\
\text { investment } \\
\text { undertakings }\end{array}$ & 35 & 696 & 0.7 & 8.6 & 0.6 \\
\hline $\begin{array}{l}\text { Foreign } \\
\text { collective } \\
\text { investment } \\
\text { undertakings }\end{array}$ & 65 & 1157 & 1.2 & 5.4 & 1.0 \\
\hline $\begin{array}{l}\text { Investment } \\
\text { holding } \\
\text { companies }\end{array}$ & - & - & - & - & - \\
\hline Pension funds & 39 & 5109 & 5.4 & 3.9 & 4.5 \\
\hline $\begin{array}{l}\text { Second pillar } \\
\text { pension funds }\end{array}$ & 30 & 4996 & 5.2 & 3.9 & 4.4 \\
\hline $\begin{array}{l}\text { Third pillar } \\
\text { pension funds }\end{array}$ & 9 & 113 & 0.1 & 4.0 & 0.1 \\
\hline $\begin{array}{l}\text { Financial } \\
\text { system }\end{array}$ & 275 & $95333 *$ & 100.0 & $3.4 *$ & 83.2* \\
\hline $\begin{array}{l}\text { Equity market } \\
\text { capitalization }\end{array}$ & - & 17275 & - & 6.7 & 15.1 \\
\hline Listed equities & - & 11344 & - & 9.8 & 9.9 \\
\hline $\begin{array}{l}\text { Listed debt } \\
\text { securities }\end{array}$ & - & 5931 & - & 1.1 & 5.2 \\
\hline
\end{tabular}


- the third level of protection is handling by the internal audit function, which performs independent and periodic verifications of organization management and internal control system (Swedbank 2012).

Moreover, not only banks by themselves are aware of liquidity risk control. Because of high impact for the economy banks are regulated in order to be safe and not to crash during the crisis. The Bank of Lithuania seeks that the country's financial services system would be safe, reliable, transparent and competitive. Lithuanian bank is responsible for issuing licenses for participants of financial market to licensed financial services, supervises their activities, monitors compliance with the laws and requirements of the Bank of Lithuania as well as the International Financial Reporting Standards, International Organizations of safe and reliable operational requirements. At the moment, commercial banks acting in Lithuania must have ratio of bank's liquid asset and current liabilities not less than 30 percent.

\section{Analysis of liquidity influence}

Recent bank crisis in all over the world has attracted increased researchers' attention for liquidity management and liquidity risk. Moreover, the recent commercial banks' failures in Lithuania raised a lot of discussions about liquidity management importance in banking sector. The risk stems from the description of banking operations (Chaplin, Emblow et al. 2000). Bank's liquidity position can affect both: its overall capital and equity and result as influence to profitability. There is a necessity to analyze whether banks' liquidity management is influencing its financial performance. Out of literature analysis a framework composed by Ahmed Arif and Ahmed Nauman Anees in 2012 was found. The framework suggests that there can be the relation between bank's liquidity and profitability examined through raising four hypotheses which are explained later on.

According to Gatev and Strahan (2003), the deposits provide a natural hedge to banks against the liquidity risk. Most of the banking operations are run through deposits, so it is natural that if the depositors start withdrawing their deposits from the bank, it will create a liquidity trap for the bank (Jeanne, Svensson 2007). This situation can force the bank to borrow funds at higher costs (Diamond, Rajan 2001). On the contrary, a bank having enough deposits in their accounts will not have the above-said problems. Therefore, to improve its profitability, it is imperative for a bank to increase its deposits (Arif, Nauman 2012). These implications are the background for the first hypothesis:

H1. Increase in deposits boosts up the earnings of the commercial bank.

A bank may have to increase its cash reserves to mitigate the liquidity risk, but it might be costly (Holmstrom, Tirole 2000). Diamond and Rajan (2001) state that a bank may refuse the lending, even to a potential entrepreneur which could bring profit for a bank at the end, if it feels that the liquidity need of the bank is quite high. The liquidity risk avoidance is a reason, why every bank tries to keep up sufficient funds to meet the unexpected demands from depositors (Majid 2003) This situation leads to the second hypothesis:

$\mathrm{H} 2$. Increase in cash reserves decreases the earnings of the bank.

The most universal measure of structural liquidity is the underlying relationship between longer-term illiquid customer loans and stable funding (in the form of customer deposits and longer-term purchased funds). A material imbalance in these relationships should prompt remedial action in order to regain control of the liquidity of the balance sheet (Falconer 2001). This situation is known as the mismatch between assets and liabilities (Brunnermeier, Yogo 2009). This mismatch can be measured with the help of the maturity gap, also called liquidity gap, between assets and liabilities (Plochan 2007). Higher liquidity gap will create liquidity risk (Plochan 2007), Therefore the third hypothesis sounds like that:

H3. Increase in the liquidity gap causes a reduction in the bank's earnings.

Many banks focus on the corporate or wholesale lending, which poses a challenge for the management to maintain the required liquidity position (Akhtar 2007). This lending is almost always long-term, which may create liquidity problems for a bank (Kashyap, Rajan et al. 2002). The loan retirement process slows down in the banks during periods of poor production of resources in the economy. This situation gives rise to non-performing loans (NPLs). When NPLs experience a rapid increase, liquidity crisis becomes inevitable. This leads to the fourth hypothesis:

H4. High provisioning for NPLs will cause a decrease in the bank's earnings.

The hypothesis raised drawing on framework composed by Ahmed Arif and Ahmed Nauman Anees in 2012 which was used to analyze Pakistani banking system. The results showed that the profitability of these banks is increased by 9.66 per cent with a unit increase in cash and vice versa. Increase in cash reserves doesn't decrease the earnings of the bank. Increase in the liquidity gap can cause 
a reduction in the bank's earnings. High provisioning for NPLs decreases bank's earnings. The conclusion was made, that liquidity risk may be mitigated by maintaining sufficient cash reserves, raising deposit base, decreasing the liquidity gap and NPLs.

In further investigation of liquidity influence for Lithuanian banks' profitability there is a need to fit the four hypotheses and conclude whether the liquidity is important factor in financial Lithuanian banks performance as well as in Pakistani banking system.

\section{Conclusions}

1. After analysis of different literature sources it can be concluded that the liquidity can be defined as companies' ability to cover its obligations without experiencing losses. The definition stress the importance of it: if a firm is not liquid enough it will be extremely vulnerable.

2. After analyzing scientists' suggestions it could be stated that liquidity risk management is an essential component of the overall risk management framework. Banks should find the way to manage the demand and supply of liquidity in an appropriate manner in order to safely run their business, maintain good relations with the stakeholders and avoid liquidity problem. Well-organized banks must have a mechanism for management of liquidity, in other words for identification, measurement, monitoring and mitigation of liquidity risk.

3. Bank's position towards liquidity can show its priorities and indicate management style, it includes a marketing aspect, as may be found in Falconer's work released in 2001.

4. There are a number of ways how companies measure the liquidity risk as a lot of scientists described. The balance sheet can be reorganized to managerial balance sheet in order to see clear state of companies' liquidity. Different ratios are often used to measure liquidity such as quick and adjusted quick ratios. Striving to evaluate the worst case scenario VaR or LaVaR may be applied.

5. There is a need for making quantitative research using framework composed by Ahmed Arif and Ahmed Nauman Anees in 2012 by using primary data taken from annual reports of Lithuanian banks. After quantitative data collection, there should be data analyzed by using SPSS statistical program in order to analyze whether Lithuanian bank's liquidity position is influencing their profitability as it does in already made analysis of Pakistani banks.

\section{References}

Akhtar, S. 2007. Pakistan: changing risk management paradigmperspective of the regulator, ACCA Conference-CFOs: The Opportunities and Challenges Ahead [online]. Karachi [cited 15 October 2013]. Available from Internet: http://www.bis. org/review/r070423c.pdf.

Arif, A.; Nauman, A. 2012. Liquidity risk and performance of banking system, The Journal of Financial Regulation and Compliance 20(2): 182-195. http://dx.doi.org/10.1108/13581981211218342

Basel Committee on Banking Supervision (BCBS). 2009c. Revisions to the Basel II Market Risk Framework, Bank for International Settlements, Basel, July.

Basel Committee on Banking Supervision (BCBS). 2010a. Results of the Comprehensive Quantitative Impact Study, Bank for International Settlements, Basel, December.

Basel Committee on Banking Supervision (BCBS). 2010b. Basel III: A Global Regulatory Framework for More Resilient Banks and Banking Systems, Bank for International Settlements, Basel, December.

Basel Committee on Banking Supervision (BCBS). 2010c. An Assessment of the Long-Term Economic Impact of Stronger Capital and Liquidity Requirements, Bank for International Settlements, Basel, August.

Bervas, A. 2006. Market liquidity and its incorporation into risk management, Financial Stability Review 8: 63-79.

Brunnermeier, M. K.; Yogo, M. 2009. A note on liquidity risk management, in AEA Session on Liquidity, Macroeconomics and Asset Prices, 12.

Chaplin, G.; Emblow, A.; Michael, I. 2000. Banking system liquidity: developments and issues, Financial Stability Review, December: $93-112$.

Comptroller of the Currency 2001. Liquidity: Comptroller's Handbook [online]. Washington [cited 12 October 2013]. Available from Internet: http://www.occ.gov/static/news-issuances/ots/trust-handbook/ots-trust-handbook-30.pdf.

Crowe, K. 2009. Liquidity risk management - more important than ever [online]. Harland Financial Solutions, p. 3 [cited 10 October 2013]. Available from Internet: https://customercenter. harlandfinancialsolutions.com/Auth/Signin?ReturnUrl=\%2fKnowlegePortal\%2fSignin\%3 freturnUrl\%3dpage\%253Dcontent \%2526id\%253 DREF4 152 \&returnUr1$=$ page $\% 3$ Dcontent $\% 26$ id $\% 3$ DREF4 152 .

Diamond, D. W.; Rajan, R. G. 2001. Liquidity risk, liquidity creation, and financial fragility: a theory of banking, The Journal of Political Economy 109(2): 287-327. http://dx.doi.org/10.1086/319552

Diamond, D. W.; Rajan, R. G. 1999. Liquidity risk, liquidity creation and financial fragility: a theory of banking, NBER Working Paper No. 7430, Journal of Political Economy 109(2): 287-327. http://dx.doi.org/10.1086/319552

Falconer, B. 2001. Structural liquidity: the worry beneath the surface, Balance Sheet 9(3): 13-19. http://dx.doi.org/10.1108/09657960110695998

Gatev, E.; Strahan, P. E. 2003. Banks' advantage in hedging liquidity risk: theory and evidence from the commercial paper market, working paper, The Wharton Financial Institutions 
Centre [online]. Chestnut Hill, MA [cited 15 October 2013]. Available from Internet: http://fic.wharton.upenn.edu/fic/ papers/03/0301.pdf.

Goddard, J.; Molyneux, P.; Wilson, J. O. 2009. The financial crisis in Europe: evolution, policy responses and lessons for the future, Journal of Financial Regulation and Compliance 17(4): 362-380. http://dx.doi.org/10.1108/13581980911004352

Guglielmo, M. R. 2008. Managing liquidity risk, Bank Accounting \& Finance 21(1): 3.

Hawawini, G.; Vialler, C. 2007. Finance for executives managing for value creation. 3rd ed. South - Western Pub Ltd. 672 p.

Holmstrom, B.; Tirole, J. 2000. Liquidity and risk management, Journal of Money Credit and Banking 32(3): 295-319. http://dx.doi.org/10.2307/2601167

Ismal, R. 2010. Strengthening and improving the liquidity management in Islamic banking, Humanomics 26(1): 18-35. http://dx.doi.org/10.1108/08288661011024977

Jeanne, O.; Svensson, L. O. 2007. Credible commitment to optimal escape from a liquidity trap: the role of the balance sheet, The American Economic Review 97(1): 474-490. http://dx.doi.org/10.1257/aer.97.1.474

Jenkinson, N. 2008. Strengthening regimes for controlling liquidity risk, Euro Money, in Conference on Liquidity and Funding Risk Management [online]. Bank of England, London, p. 9 [cited 10 October 2013]. Available from Internet: https:// www.bis.org/review/r080425f.pdf.

Kashyap, A. K.; Rajan, R.; Stein, J. C. 2002. Banks as liquidity providers: an explanation for the coexistence of lending and deposit-taking, The Journal of Finance 57(1): 33-73. http://dx.doi.org/10.1111/1540-6261.00415

The Bank of Lithuania [online], [cited 10 October 2013]. Available from Internet: http://www.lb.lt/lietuvos_ekonomika.

Majid, A. R. 2003. Development of liquidity management instruments: challenges and opportunities, in International Conference on Islamic Banking: Risk Management, Regulation and Supervision, Jakarta - Indonesia, 24.

Muranaga, J.; Ohsawa, M. 2002. Measurement of liquidity risk in the context of market risk calculation [online]. Institute for Monetary and Economic Studies, Bank of Japan, Tokyo [cited 13 October 2013]. Available from Internet: https:// www.bis.org/publ/ecsc07j.pdf.

Peles, C. Y.; Schneller, I. M. 1979. Liquidity ratios and industry averages - new evidence, Abacus 15(1): 13-22. http://dx.doi.org/10.1111/j.1467-6281.1979.tb00070.x

Plochan, P. 2007. Risk management in banking: Master thesis. University of Economics, Bratislava.

Ross, J. 2000. Liquidity and the markets, Balance Sheet 8(2): $31-32(2)$.

Siddiqi, N. 2008. Current financial crisis and Islamic economics [online]. Aligarh, India [cited 13 October 2013]. Available from Internet: http://www.siddiqi.com/mns/ CurrentFinancialCrisisAndIslamicEconomics.htm.

Swedbank. Annual Report 2012 [online], [cited 9 October 2013]. Available from Internet: http://www.swedbank.lt/ files/ataskaitos/2012f.pdf.

Titus, M. E.; Lewis, D. 1997. Introduction, in VaR. Understanding and applying valueat-risk, Risk Publications, London, 1 edition. 397. ISBN-13: 978-1899332267.
Varotto, S. 2011. Liquidity risk, credit risk, market risk and bank capital, International Journal of Managerial Finance 7(2): 134-152. http://dx.doi.org/10.1108/17439131111122139

Zhu, H. 2001. Bank runs, welfare and policy implications, Bank for International Settlement Working Paper No. 107, Basel [online], [cited 9 October 2013]. Available from Internet: http://www.atl-res.com/finance/financeconference/zhu.pdf.

\section{LIKVIDUMO RIZIKA IR JOS VALDYMAS LIETUVOS BANKŲ SISTEMOJE}

\section{E. Bareikaitè, R. Martinkutè-Kaulienè}

\section{Santrauka}

Išanalizuota likvidumo svarba ir jo įtaka Lietuvos bankų veiklai. Išnagrinèti ir pateikti likvidumo vadybos bei valdymo Lietuvos bankininkystès sektoriuje principai. Likvidumo svarbos analizė pateikta ir apibendrintai, remiantis istoriniais įvykiais bei mokslinès literatūros apžvalga. Išnagrinètos skirtinguose šaltiniuose vartojamos likvidumo sąvokos. Pateikta likvidumo rizikos ir jos valdymo būdų apžvalga, aprašyti likvidumo vertinimo komponentai. Iškeltos ir aprašytos hipotezès ryšiui tarp likvidumo ir pelningumo nustatyti bei pateikta siūlymų tolesniam tyrimui.

Reikšminiai žodžiai: likvidumas, likvidumo rizika, bankų likvidumo valdymas, likvidumo koeficientai, Lietuvos bankų sistema. 